\title{
DINAMIKA PAS (MALAYSIA) DAN PKS (INDONESIA) DALAM PERJUANGAN MEWUJUDKAN NEGARA ISLAM, 1998-2008
}

\author{
Amin Fadlillah \\ Mohammad Redzuan Othman
}

\begin{abstract}
The formation of an Islamic state was initially an ultimate aim for Muslim political parties in Malaysia and Indonesia in 1950s. However, recently there has been a change of ideology shown by the Islamic political parties due to the change in situation and the political environment. In Malaysia, Parti Islam Se-Malaysia (PAS) has consistently championed the establishment of an Islamic state since its founding. However, the PAS has changed its political manifesto, from the struggle for an Islamic state to establishment of a welfare state. This came after the party received an overwhelming support among the non-Muslims in the 2008 General Election. The change in ideology indicates the change in approach and political strategy; from a rigid and conservative approach to a more pragmatic, rational and realistic strategy. In Indonesia, the change of approach was evident in Partai Keadilan Sejahtera (PKS). The party moved from strictly championing Islam to a more open party in 2008. The change in strategy means that both parties are no longer uses issues and ideals that have become synonymous with their mission such as the implementation of hudud and the application of Islamic law. In contrast, PAS and PKS are now highlighting an inclusive political stance by focusing on issues and party programs that had been given less attention formerly.
\end{abstract}

\section{Pengenalan}

Perjalanan parti politik yang memperjuangkan tegaknya negara Islam mengalami jalan yang sukar dan penuh berliku. Pada peringkat awal 
iaitu pada tahun 1950-an, parti politik Islam menyerlahkan semangat, persefahaman, persatuan dan sentimen yang kuat dalam usahanya menegakkan negara yang berteraskan prinsip Islam. Bagaimanapun, dalam konteks kekinian terutama setelah gerakan reformasi pada 1998, politik Islam seolah-olah kehilangan halatuju prinsip perjuangan berikutan dinamika politik kelas tinggi yang memaksa mereka merubah ideologi politiknya. Meskipun sebelumnya parti politik Islam banyak memberikan harapan yang cukup mencerahkan akan terbentuknya masyarakat dan negara yang Islamik menerusi pembangunan Islam dan proses Islamisasi yang rancak, namun disebabkan pergelutan dan konflik politik secara dalaman, usaha itu cukup terjejas. Tambahan lagi, wujud satu persepsi negatif terhadap kalangan Islam politik berikutan peristiwa penyerangan gedung World Trade Centre (WTC) New York dan Pentagon pada 11 September 2001. Peristiwa itu telah mencoreng Islam sebagai agama peradaban dunia dan pencipta tamadun unggul dalam sejarah kehidupan manusia.

Perkembangan politik semasa di Malaysia dan Indonesia terutama selepas pilihan raya pada 2004 menunjukkan hal yang sebaliknya. Isu negara Islam menjadi isu yang cukup kontroversi berikutan wujudnya penolakan, tidak saja datang daripada parti politik yang berasaskan nasionalisme atau sekularisme, akan tetapi penolakan juga datang daripada NGO-NGO Islam (terutama yang berlaku di Indonesia) yang lebih menerima bentuk sistem kenegaraan semasa. Sistem dan perlembagaan yang sedia ada dianggap sebagai bentuk yang ideal memandangkan komposisi masyarakat di kedua-dua negara berbeza agama, bahasa, etnik, budaya dan adat resam.

\section{Polemik Negara Islam}

Isu negara Islam merupakan modal utama sesebuah parti politik Islam yang menjadi elemen pembeza dengan parti politik yang mengusung ideologi nasional, bahkan sekular, meskipun parti tersebut berasaskan kepada sokongan umat Islam. Isu negara Islam menjadi tarikan yang luar biasa bagi aktivis Islam untuk dijelmakan dalam realiti politik. Malah, dalam komponen aktivis Islam itu sendiri, perjuangan untuk mendirikan negara Islam dianggap sebagai fardhu ain bagi setiap muslim untuk mewujudkannya dan berdosa jika tidak dilaksanakan. ${ }^{1}$ Oleh yang demikian, tidak menghairankan jika di kemudian hari, dalam menentukan bentuk kenegaraan, iaitu sama ada negara berasaskan kepada negara Islam atau negara berdasarkan kebangsaan, telah berlaku pertembungan ideologi yang cukup sengit di antara kedua belah pihak yang seolah-olah tiada penghujungnya. Masing-masing mempunyai pendirian dan hujah yang rasional yang semuanya berasaskan kepada 
realiti keadaan sosio-politik masyarakat yang diwakili oleh pihak masing-masing.

Pada hakikatnya, kontroversi negara Islam di Malaysia dan Indonesia berlaku sejak awal negara merdeka lagi. Terdapat dua aliran politik yang mewakili pandangan dan sikap politik arus perdana iaitu golongan yang menghendaki terbentuknya negara Islam dan golongan nasionalis-sekularis yang menginginkan negara yang berasaskan kepada perlembagaan yang mencerminkan bebas (neutral) daripada dominasi agama tertentu (Islam). ${ }^{2}$ Pertembungan ideologi ini terjelma dalam bentuk parti politik yang memperjuangkan aspirasi masingmasing dalam usaha mereka untuk merumuskan dan menentukan ideologi negara.

Di Malaysia, dari segi sejarahnya, konflik ideologi ini dimanifestasikan dalam pertembungan dua parti iaitu United Malays National Organisation (UMNO), mewakili parti nasionalis dan Parti Islam Se-Malaya (PAS) sebagai parti yang menghasratkan wujudnya negara Islam. ${ }^{3}$ Perbincangan atau isu yang berkaitan dengan pelaksanaan Islam di Malaysia tidak lepas daripada kewujudan dua parti tunjang orang Melayu. ${ }^{4}$ Sejak awal tahun 1950-an lagi, isu tentang kepentingan kewujudan negara Islam dengan pelbagai terminologi, takrif dan interpretasinya tertumpu kepada persaingan dan perlumbaan untuk meraih sokongan kaum Melayu. ${ }^{5}$ Masing-masing berusaha untuk menonjolkan keislamannya menerusi pendekatan yang berbeza-beza tanpa meninggalkan identiti dan jatidiri parti berkenaan. Bagaimanapun, pertembungan di antara PAS vis-a-vis UMNO tidak menggambarkan konflik ideologi yang serius yang mengakibatkan pertembungan peringkat akar umbi di antara penyokong kedua parti. Akan tetapi konflik ideologi tersebut lebih banyak diwarnai dengan polemik dan tafsiran yang berbeza mengenai konsep negara Islam. ${ }^{6}$

Sebagai parti yang berkuasa di Malaysia, UMNO yang disokong oleh gabungan parti bukan Melayu di dalam Barisan Nasional (BN), menganggap bahawa sistem kenegaraan dan perlembagaan Malaysia yang sedia ada sudah sesuai disebut sebagai negara Islam. Bagi UMNO, yang menjadi tulang belakang daripada pemerintah, pembangunan Islam yang telah dijalankan dan yang sedang diusahakan semenjak awal merdeka pada 1957 sehingga ke hari ini, telah menepati ciriciri negara Islam. ${ }^{7}$ Dengan mempertimbangkan struktur masyarakat Malaysia yang pelbagai kaum, agama, bahasa, budaya dan tradisi, pendekatan dan amalan Islam yang moderat dan pragmatik adalah satu kaedah yang dapat diterima oleh semua rakyat terutama daripada kalangan bukan Islam. Pelaksanaan Islam menurut UMNO tidak hanya berdasarkan kepada keindahan retorik semata-mata, tetapi Islam harus 
dilaksanakan secara praktikal yang diselaras dengan realiti dan sosiopolitik masyarakat. ${ }^{8}$

Manakala bagi PAS, kewujudan perlembagaan dan sistem politik sedia ada sama sekali tidak mencerminkan kriteria sebagai negara Islam. Menurut PAS, hal ini merujuk kepada perlembagaan negara yang masih mengekalkan warisan perlembagaan kolonial British, tidak dilaksanakan syariat Islam di dalam pentadbiran dan undang-undang, mengekalkan peraturan kafir dan unsur asabiah yang masih kuat. ${ }^{9}$ Islam yang diamalkan dan diterapkan oleh UMNO dalam pembangunan politik hanya sekadar pelapis muka sahaja (cosmetic) dan tidak mengamalkan ajaran Islam yang sebenar. Ini disebabkan pada masa yang sama, UMNO dengan kerajaan Barisan Nasional-nya, dituduh mengekang kebebasan rakyat dan bertindak zalim dengan wujudnya beberapa akta seperti, ISA, Akta OSA, AUKU dan sebagainya yang bertentangan dengan ajaran Islam yang menjunjung tinggi kehormatan dan kebebasan manusia. ${ }^{10}$

PAS menganggap pelaksanaan Islam oleh UMNO hanya bermotif politik semata-mata dan bagi menarik sokongan umat Islam untuk survivalnya serta tidak didasari oleh keinsafan dan penghayatan terhadap ajaran Islam. ${ }^{11}$ Islam versi UMNO dilaksanakan untuk menonjolkan imej bahawa Islam adalah tidak lari daripada perjuangan UMNO. ${ }^{12}$ Pokoknya, PAS berpendapat hanya negara Islam yang dikonsepsikan oleh PAS sahaja yang dapat menyelesaikan pelbagai masalah yang timbul. Oleh sebab itu, PAS berpendirian negara Islam adalah tawaran yang tidak diberi tolak ansur dan menjadi matlamat akhir dalam kancah percaturan politik negara. ${ }^{13}$

Jika di Malaysia gagasan dan wacana negara Islam banyak ditentukan oleh persaingan dan pertembungan antara PAS dan UMNO, lain halnya dengan di Indonesia. Dalam konteks Indonesia, pertarungan wacana dan praktik gagasan negara Islam selain ditunjangi oleh parti politik, turut ditentukan oleh kuasa dan pendirian politik pertubuhan bukan kerajaan (NGO) Islam khususnya daripada Nahdlatul Ulama (NU) dan Muhammadiyah. Dari segi sejarahnya, aspirasi umat Islam di Indonesia untuk menubuhkan negara Islam disalurkan menerusi parti Masyumi, satu-satunya wadah politik umat Islam, sejak awal merdeka lagi pada 1945. Tidak sebagaimana yang berlaku di Malaysia di mana aspirasi umat Islam terpecah kepada UMNO dan PAS, pada 1940-an suara umat Islam di Indonesia bersatu padu bagi menyuarakan aspirasi untuk menegakkan negara Islam. Semua kelompok Islam baik daripada golongan modenis mahupun tradisionalis mempunyai visi dan pendirian yang sama menerusi Masyumi. Segala perbezaan dan pertentangan yang sebelum ini berlaku antara aliran Islam itu, tidak timbul. ${ }^{14}$ 
Halangan utama yang dihadapi golongan Islam adalah datang daripada golongan luar iaitu golongan nasionalis, sekularis dan komunis. Ketiga-tiga aliran politik ini yang dapat menggagalkan impian umat Islam menubuhkan negara Islam. Ini bermakna, secara dalaman parti politik Islam kukuh dan kuat. Hanya, disebabkan oleh faktor luaran yang menjadi elemen penghalang, realisasi penubuhan negara Islam tidak tercapai. Ditambah lagi dengan keputusan pilihan raya pertama pada 1955 yang menyaksikan gabungan parti Islam hanya memperoleh 43.5 peratus dan gagal meraih majoriti $2 / 3$ bagi menggubal perlembagaan negara berdasarkan Islam. ${ }^{15}$

Oleh kerana kekuatan parti politik Islam tidak mencukupi untuk meminda perlembagaan, usaha ke arah itu berhenti di tengah jalan. Ditambah lagi dengan pengharaman Presiden Soekarno terhadap Masyumi pada 1960 yang dianggap terlibat dalam pemberontakan terhadap pemerintahan pusat, gagasan atau usaha menubuhkan negara Islam menjadi misi yang tidak mungkin terlaksana. Kemunculan rejim Soeharto pada tahun 1966, yang begitu fobia dengan isu negara Islam menjadikan isu berkenaan terkubur seiring dengan beberapa dasar dan peraturan yang bersifat diskriminatif dan meminggirkan kekuatan politik Islam dalam semua aspek pentadbiran negara. ${ }^{16}$ Menerusi jentera Orde Baru, Soeharto tidak mahu membiarkan kekuatan politik Islam mempengaruhi dan meraih sokongan umat Islam. Pada masa pemerintahannya, Soeharto mengarahkan beberapa parti politik Islam digabungkan (difusi parti) ke dalam satu parti, bagi tujuan melemahkan politik Islam dan dapat mengawal potensi gabungan Islam di mana pada era Orde Lama meraih undi terbanyak. ${ }^{17}$

\section{Proses Perubahan Ideologi}

Dalam konteks Malaysia, pertembungan ideologi yang berkaitan dengan negara Islam sudah berlaku pada era sebelum merdeka. Ini ditandai dengan keluarnya sayap ulama dalam UMNO dan kemudian menubuhkan parti sendiri, iaitu Parti Islam Se-Malaya (PAS). ${ }^{18}$ Pertembungan antara golongan Melayu-nasionalis dan Melayu-Islamis di dalam UMNO pada masa itu menunjukkan wujudnya konflik ideologi yang cukup serius dalam menentukan dasar dan bentuk negara. Dalam hal ini, kedudukan kedua kubu (UMNO dan PAS) adalah jelas, tegas dan saling bertentangan. Di satu pihak menegaskan pendirian fahaman kebangsaan, manakala di pihak yang lain secara tegas menghendaki wujudnya negara Islam. ${ }^{19}$

Pada masa yang sama, UMNO sebagai pihak yang mendukungi fahaman kebangsaaan berusaha secara terus menerus melakukan kempen peng-nyahan negara Islam yang selama ini diperjuangkan PAS. 
Sebagai parti yang berkuasa di Malaysia semenjak merdeka pada 1957, UMNO membuat politik pengimejan (political perceptions) menerusi dasar Islamisasi yang rancak dalam pelbagai wilayah birokrasi pada era pemerintahan Mahathir Mohamad seperti Islamisasi pada wilayah pentadbiran, ${ }^{20}$ sistem kehakiman dan perundangan, ${ }^{21}$ ekonomi, ${ }^{22}$ dan pendidikan. ${ }^{23}$ Projek Islamisasi ini juga diteruskan oleh Abdullah Badawi dengan pendekatan Islam Hadhari. ${ }^{24}$ Politik pengimej-an menerusi Islam Hadhari ini telah menjadi unsur dan angkubah penting dalam mengembalikan kejayaan UMNO pada pilihan raya 2004 selepas tercalit dengan kes pemecatan dan pemenjaraan Anwar Ibrahim. Politik Islamisasi ini selain termotivasi untuk menunjukkan elemen keislaman yang ingin ditonjolkan UMNO, ia juga bertujuan untuk meleraikan dakwaan-dakwaan PAS yang menyatakan hanya PAS sahaja yang mampu memperjuangkan dan memartabatkan syiar dan dakwah Islam di Malaysia. ${ }^{25}$

Sesungguhnya gagasan negara Islam di Indonesia sudah tamat dengan keluarnya dekrit Presiden ${ }^{26}$ pada 1959 yang menegaskan ideologi negara adalah Pancasila dan Undang-Undang Dasar (perlembagaan negara) yang terhasil daripada kemerdekaan pada 1945. Tanda-tanda 'kekalahan' parti Islam dalam memperjuangkan negara Islam sebenarnya sudah dapat dilihat dengan terbatalnya Piagam Jakarta untuk dimasukkan dalam perlembagaan negara menjelang kemerdekaan Indonesia pada $1945 .{ }^{27}$ Meskipun pada masa itu golongan Islam daripada pelbagai unsur dan parti politik bersatu padu dalam menyuarakan hasrat menegakkan negara Islam, akan tetapi kehendak itu tidak tercapai. Kegagalan mempertahankan Piagam Jakarta ini menjadi isyarat kepada perkembangan politik kebangsaan di kemudian hari yang menyaksikan siri kegagalan parti-parti Islam dalam menubuhkan negara Islam sama ada pada pasca merdeka (dalam sidang konstituante) mahupun pada era reformasi pasca tumbangnya rejim Orde Baru. ${ }^{28}$

Ketidakupayaan dan kegagalan parti politik Islam untuk mewujudkan negara Islam kemudian menjadi asas dan pertimbangan beberapa tokoh Islam yang tergabung dalam Nahdlatul Ulama (NU) dan Muhammadiyah yang menyatakan bahawa negara Indonesia dengan ideologi Pancasila merupakan ideologi terbaik bagi rakyat Indonesia. ${ }^{29}$ Pendirian kedua pertubuhan terbesar di Indonesia itu yang menolak wujudnya negara Islam, memberi tamparan hebat kepada golongan Islam yang ada dalam parti politik yang masih terus berusaha memperjuangkan negara Islam. Hal ini kerana, NU dan Muhammadiyah menjadi simbol kepada kewujudan umat Islam di Indonesia yang menjadi paksi kepada pendirian sederhana. Aspirasi dan pernyataan kedua pertubuhan ini merupakan manifestasi daripada arus 
perdana Islam yang merupakan suara majoriti umat Islam di Indonesia. ${ }^{30}$ Walhal, pendirian kedua organisasi Islam yang sangat berpengaruh itu, menjejaskan usaha dan impian parti Islam yang menghendaki berdirinya negara Islam.

Faktor lain yang turut mencetuskan proses penyahan ideologi negara Islam di Indonesia adalah wujudnya pemikiran dan pembaharuan intelektualisme di kalangan tokoh muda Islam yang diterajui oleh Nurcholish Madjid pada era 1970-an. ${ }^{31}$ Golongan pembaharu ini berpandangan bahawa perjuangan untuk menegakkan negara Islam adalah satu perjuangan yang hanya menghabiskan tenaga dan pemikiran yang tiada berkesudahan. Hal ini kerana mereka perlu berhadapan dengan satu pemerintahan autoritarian yang secara tegas tidak akan menerima sebarang aspirasi berkenaan dengan keinginan menubuhkan negara Islam. Satu perjuangan yang dianggap mustahil ketika itu sehingga melupakan tugas dan fungsi mereka sebagai penyambung kepentingan umat Islam dalam arus pembangunan negara dan memperjuangkan kebajikan umat Islam. ${ }^{32}$

Oleh sebab itu, mereka menolak gagasan negara Islam kerana dianggap akan meminggirkan potensi umat Islam yang sepatutnya menjadi kekuatan yang besar dan menjadi pemain utama dalam pelaksanaan Islam di Indonesia. ${ }^{33}$ Menerusi slogan "Islam yes, partai Islam no!" yang terkenal, ${ }^{34}$ golongan intelektual ini menyeru pentingnya satu hubungan yang harmoni dan saling mengisi di antara pemerintah dan kaum Islam bagi membolehkan umat Islam turut menentukan masa depan bangsa dan negara. ${ }^{35}$ Ringkasnya, mereka lebih menekankan bentuk Islam yang substansial serta menolak pelaksanaan Islam secara formal tanpa meninggalkan prinsip-prinsip dasar dalam Islam. ${ }^{36}$

Penting juga untuk dicatat di sini tentang berlakunya proses penyahan ideologi negara Islam di Indonesia yang diakibatkan oleh faktor luaran. Faktor luaran yang dimaksudkan di sini adalah usaha-usaha penyahan ideologi negara Islam yang dilakukan oleh pemerintah terutama yang berlaku pada era Soeharto. Pada peringkat awal kekuasaan Orde Baru pada 1966, tercetus harapan kaum Islamis kepada Soeharto untuk dapat memulihkan hubungan yang terjejas teruk dengan pemerintah Soekarno memandangkan peranan dan sumbangan golongan Islam dalam menumpas gerakan 30 September yang didalangi komunis pada 1965 mengakibatkan tumbangnya Soekarno. Bukannya membina hubungan yang baik dan harmonis, sebaliknya kerajaan Orde Baru yang autoritarian itu menggunakan pendekatan dan cara yang represif dalam menghadapi golongan Islam politik yang dianggap menyimpan potensi yang besar bagi menggugat dan mengancam kekuasaan rejim yang baru diraih. ${ }^{37}$ 
Beberapa bentuk penolakan Orde Baru untuk mencipta hubungan yang harmonis dengan golongan Islam politik adalah penolakan rejim untuk menghidupkan semula parti Masyumi yang diharamkan pada era Soekarno. ${ }^{38}$ Penolakan Soeharto ini dapat ditafsir sebagai satu cara untuk melakukan proses penyahan ideologi negara Islam kerana selama ini Masyumi dikenali sebagai parti yang secara gigih dan konsisten memperjuangkan Islam sebagai ideologi negara. Selain itu, oleh kerana fobia terhadap Islam politik, Orde Baru mengeluarkan peraturan tentang penyatuan parti politik (difusi parti). Parti-parti politik Islam (NU, Parmusi, Perti dan PSII) disatukan menjadi satu parti iaitu Partai Persatuan Pembangunan (PPP) sebagai satu-satunya wadah saluran politik Islam. Penyatuan parti politik di bawah satu payung bertujuan untuk membatasi, menyekat dan mengawal perjalanan parti agar tidak berkembang menjadi parti yang besar dan berpengaruh dalam kalangan umat Islam. Dengan menjadi satu wadah dalam satu parti, pihak berkuasa berkeyakinan PPP akan menjadi medan konflik baru kepada parti-parti Islam yang mempunyai latar belakang dan mewakili aliran Islam yang berbeza-beza. Dengan begitu, parti ini tidak akan berkembang menjadi parti yang besar disebabkan adanya perebutan kuasa di kalangan mereka sendiri. ${ }^{39}$

Selain melakukan pendekatan represif kepada parti politik, rejim Orde Baru juga menggunakan kaedah yang sama kepada kelompokkelompok Islam di luar parti politik yang menunjukkan penentangan kepada rejim Orde Baru. Malah, dalam kes tertentu, pihak rejim Orde Baru menggunakan pendekatan kekerasan bagi menangani cabaran golongan Islam seperti dalam kes Tanjung Priok pada $1984,{ }^{40}$ kes Jamaah Imran yang terbabit dalam rampasan kapal terbang Garuda Woyla pada 1981, ${ }^{41}$ dan penumpasan kelompok Warsidi di Lampung pada tahun $1989 . .^{42}$ Ketiga gerakan Islam radikal ini menolak sistem politik dan ideologi negara Indonesia yang dianggap terkeluar daripada ajaran Islam dan menghendaki wujudnya negara Islam di Indonesia. Dengan adanya gerakan Islam radikal yang bercita-cita menegakkan negara Islam ini, rejim Orde Baru semakin memperhebatkan proses penyahan ideologi negara Islam dengan membuat peraturan dan undang-undang yang bertujuan untuk menyekat dan mengawal aktiviti gerakan Islam. ${ }^{43}$

Perkara yang paling ketara dalam melihat tindakbalas rejim Orde Baru terhadap cabaran kelompok Islam yang menghendaki negara Islam adalah wujudnya undang-undang yang menetapkan Pancasila sebagai satu-satunya asas parti politik dan pertubuhan. Perkara ini menjadi kemuncak kepada penyahan ideologi yang dirancang secara sistematik oleh pihak rejim Orde Baru untuk melumpuhkan dan menyekat Islam politik daripada membuat aktiviti politik yang boleh 
mempengaruhi umat Islam. Penetapan undang-undang ini juga bagi membolehkan pihak berkuasa bertindak kepada mana-mana pihak yang menolak atau membantah undang-undang tersebut. Dengan adanya undang-undang ini, satu-satunya parti politik Islam iaitu PPP, tidak dibenarkan lagi menggunakan Islam sebagai asas parti. Ini termasuk lah penggunaan simbol-simbol Islam seperti bulan, bintang dan gambar ka'bah diharamkan untuk dijadikan simbol parti. Perkara yang sama juga berlaku kepada pertubuhan Islam yang tidak dibenarkan mencantumkan Islam sebagai ideologi atau asas pertubuhan. ${ }^{44}$

Perbezaan penting yang lainnya di antara Malaysia dan Indonesia dalam menghadapi polemik negara Islam terletak kepada cara dan pola yang dilakukan oleh pimpinan tertinggi di kedua-dua negara. Wujud strategi dan cara yang berbeza dalam mengurus cabaran isu negara Islam ini. Di Malaysia, Mahathir Mohamad tidak menunjukkan sikap dan pendirian yang negatif menghadapi aktivisme Islam yang menghendaki penubuhan negara Islam. Malah, secara terbuka Mahathir mengisytiharkan Malaysia sebagai negara Islam di hadapan kaum Cina yang bersidang dalam Perhimpunan Agung Parti Gerakan pada September 2001. ${ }^{45}$ Tidak sebagaimana Soeharto yang begitu alergik dan fobia kepada semua perkara yang berbau Islam, sebaliknya Mahathir menjadikan Islam sebagai bahagian penting dalam pentadbiran dan pembangunan politiknya (inclusion).$^{46}$ Cabaran dan aktivisme Islam ditangani oleh Mahathir dengan cara yang lembut iaitu menampung aspirasi (accomodation), mengambil mereka sebagai pegawai kerajaan (co-option) dan sedikit konfrontasi kepada pihak-pihak yang secara melampau menentang kerajaan. ${ }^{47}$

Di pihak lain, Soeharto mengetepikan peranan Islam sebagai unsur yang dominan dalam pembangunan politiknya (exclusion). ${ }^{48}$ Islam dianggap sebagai penghalang kepada pembangunan negara yang diperlukan Indonesia yang mengalami krisis ekonomi cukup parah. Islam dituduh sibuk memikirkan persoalan ideologi (bersifat eksklusif) berbanding memikirkan secara inklusif iaitu bagaimana mengukuhkan lagi perpaduan dan integrasi di antara semua agama dan golongan masyarakat dalam membangun negara. Lebih daripada itu, Soeharto juga beranggapan Islam politik merupakan ancaman kepada kestabilan dan keharmonian negara kerana kerasnya tuntutan mereka untuk menubuhkan negara Islam. Persepsi Soeharto terhadap Islam ini tidak lari daripada beberapa rentetan peristiwa pemberontakan atas nama Islam yang menghendaki negara Islam seperti pemberontakan Darul Islam pada 1949, PRRI/Permesta pada 1957 dan beberapa kes keganasan yang lainnya. Pelbagai peristiwa yang digerakkan oleh kelompok Islam sangat mempengaruhi pandangan Soeharto terhadap aktivisme 
politik Islam sehingga menyerlahkan sikapnya yang tidak ramah dan meminggirkan peranan Islam dalam arus pembangunan negara.

\section{Dari Perjuangan Ideologi Ke Perjuangan Pragmatik}

Pada perkembangan seterusnya, dinamika isu negara Islam berkembang kepada proses perubahan disebabkan faktor dalaman yang berlaku dalam kalangan Islam politik. Perubahan pendekatan dan watak politik yang diserlahkan parti Islam di Malaysia dan Indonesia ini merupakan tindak balas dan strategi politik baru yang cuba ditampilkan bagi menyesuaikan sentimen politik yang tidak sama pada masa sebelumnya. Persekitaran dan corak politik baru ini semakin menonjolkan isu-isu sejagat yang juga menjadi nilai-nilai murni kepada semua kepercayaan dan agama seperti rasuah, salah guna kuasa dan urus tadbir yang baik (good government). Isu ini telah melangkaui isu-isu eksklusif (penubuhan negara Islam) yang selama ini menjadi garis sempadan antara parti Islam dan bukan Islam seperti pelaksanaan hudud dan penerapan syariat Islam. ${ }^{49}$

Dalam konteks di Malaysia, dapat dilihat dalam pasca pilihan raya 2008 yang menyaksikan kejayaan gabungan pembangkang menafikan tradisi kemenangan 2/3 Barisan Nasional yang mencetuskan tsunami politik. ${ }^{50}$ Berikutan kejayaan pakatan pembangkang dalam pilihan raya yang merupakan sejarah pertama kali dalam persada politik Malaysia, telah dibentuk Pakatan Rakyat (PR). Pakatan ini ditubuhkan bagi memperkukuh kerjasama dan perpaduan di antara komponen parti pembangkang yang terdiri daripada PKR, DAP dan PAS. ${ }^{51}$ Kewujudan PR menunjukkan berlakunya sentimen dan persekitaran politik baru yang bebas daripada isu-isu perkauman yang selama ini menjadi perspektif perdana dalam percaturan politik di negara ini.

Bagaimanapun, masuknya PAS dalam gabungan pembangkang memberi kesan kepada prinsip parti sehingga dilihat menyingkirkan prinsip parti yang selama ini konsisten dipegang teguh PAS khususnya pendiriannya tentang negara Islam. Menyedari bahawa pendiriannya yang tidak mengenal kompromi terkait isu negara Islam mengakibatkan terpecahnya Barisan Alternatif (BA) pada pilihan raya 2004, ${ }^{52}$ PAS mula menunjukkan pendirian yang moderat dan kompromi menghadapi pilihan raya pada 2008. Perubahan strategi politik PAS ini juga berdasarkan kepada fakta keputusan pilihan raya 2004 yang menyaksikan PAS kalah teruk. Kekalahan ini amat berbeza dengan keputusan pilihan raya 1999 di mana PAS berjaya meraih sokongan dan menjadi ketua pembangkang. ${ }^{53}$ Salah satu faktor kekalahan itu adalah diakibatkan oleh 'kedegilan' PAS yang melancarkan manifesto negara Islam. Hal ini ditambah lagi dengan cubaan PAS menerapkan 
hudud di Terengganu. Perkara-perkara in menimbulkan kecurigaan dan perasaan tidak senang dalam kalangan pengundi bukan Islam. Meskipun ditinggalkan rakan politiknya iaitu DAP, PAS tetap bertegas mempertahankan konsep negara Islam mereka dengan melancarkan dokumen negara Islam sebagai bahan kempen menjelang pilihan raya 2004. ${ }^{54}$

Melalui integrasi PAS dalam Pakatan Rakyat secara tidak langsung PAS harus merasional dan menyesuaikan persekitaran politiknya dengan sekutu-sekutu politiknya yang merupakan penjelmaan daripada pelbagai ideologi. Hal ini dapat dilihat dengan tindakan PAS pada 2008 yang tidak lagi mengangkat konsep negara Islam sebagai manifesto politiknya, tetapi merubah negara Islam menjadi negara berkebajikan. ${ }^{55}$ PAS berhujah bahawa penggunaan negara berkebajikan dalam persediaan menghadapi pilihan raya ke-13 itu adalah tidak bertentangan dengan ajaran Islam. ${ }^{56}$ Hal ini kerana dalam negara berkebajikan terdapat prinsip-prinsip umum yang menjadi asas dalam ajaran Islam yang diterapkan bagi membuat kebajikan kepada semua rakyat tanpa memandang agama, etnik dan bangsa seperti pendidikan percuma, penghapusan tol, skim kesihatan, akta gaji minima dan menurunkan harga petrol. ${ }^{57}$

Pendirian PAS yang tidak lagi menggunakan negara Islam sebagai bahan kempennya menunjukkan berlakunya dinamika pemikiran dan strategi politik di dalam parti itu. PAS tidak lagi terjebak dengan retorik-retorik indahnya tentang dasar Islam yang selama ini tidak boleh bertolak ansur. Sebaliknya, PAS mengutamakan isi dan asas (substance) prinsip Islam tanpa harus melabel pelaksanaan negara berkebajikan itu ditakrif sebagai negara Islam. Ini termasuk keberanian PAS yang tidak lagi menyentuh hudud dalam manifesto negara kebajikan yang dilancarkannya. ${ }^{58}$

Perubahan yang berlaku pada PAS membuktikan wujudnya proses penyahan ideologi negara Islam secara dalaman. Realiti ini tidak berlaku pada tahap awal penubuhan hingga sebelum pilihan raya ke-12 yang mana proses perubahan negara Islam lebih banyak dipengaruhi oleh faktor luaran yang diakibatkan oleh pertembungan ideologis antara PAS dan UMNO. Terdapat beberapa faktor yang menjadi elemen penting dalam mengamati dinamika dalaman PAS terkait penyingkiran agenda negara Islam sebagai asas perjuangan PAS yang menjurus kepada proses penyahan ideologi negara Islam iaitu;

Pertama, kekalahan PAS dalam Pilihan Raya ke-11 pada 2004. Dalam pilihan raya ini, imej PAS sebagai parti tradisionalis, konservatif dan fundamentalis amat menonjol. Hal ini dikaitkan dengan kesan serangan WTC New York pada 11 September 2001. Serangan oleh pengganas ini menimbulkan simpati umat Islam di seluruh dunia termasuklah 
di Malaysia dengan wujudnya gerakan Islam radikal yang dikenali sebagai Kumpulan Mujahidin Malaysia (KMM). Kumpulan ini diketuai oleh Nik Adli Nik Aziz, anak kepada Mursyidul Am PAS Nik Aziz Nik Mat. ${ }^{59}$ Oleh itu, ramai pengundi bukan Islam yang mengaitkan PAS dengan wajah Islam yang militan dan radikal sehingga menimbulkan keraguan bukan Islam terhadap keupayaan PAS mentadbir negara sekiranya diberi peluang memerintah. ${ }^{60}$ Keyakinan dan kepercayaan diri PAS yang tinggi setelah kemenangan besar PAS pada pilihan raya 1999, membuat PAS bertindak egois dan tidak banyak membawa perubahan yang bererti dalam menonjolkan imej parti sebagai parti yang sederhana, moden dan reformis yang boleh merangkul semua elemen dalam masyarakat Islam dan bukan Islam. ${ }^{61}$ Sebaliknya, PAS kekal sebagai parti yang keras dan kaku sehingga menakutkan bukan Islam untuk memilih parti itu. Malah, keyakinan PAS yang tinggi terhadap pendekatan ini diterjemahkan dengan melancarkan Dokumen Negara Islam sebagai bekal menghadapi pilihan raya 2004. ${ }^{62}$ Akibat pendekatan yang tidak pragmatik ini, PAS ditinggalkan rakan politiknya DAP dalam gabungan Barisan Alternatif (BA) yang tidak bersetuju dengan pendirian PAS yang akan mendirikan negara Islam jika mereka diberi peluang memerintah negara. ${ }^{63}$

Kedua, keputusan Pilihan Raya ke-12. Ketika menghadapi pilihan raya pada 2008, PAS telah merubah pendirian negara Islam kepada negara berkebajikan. Menyedari akan kesilapan strategi politik, pendekatan dan politik pengimejan yang dibuat pada pilihan raya 2004, PAS tidak mahu mengulangi kesilapan yang sama pada pilihan raya 2008. Hasilnya, PAS bersama pakatan pembangkang bangkit semula dan berjaya menafikan kemenangan tradisi 2/3 BN dan merampas beberapa negeri dari penguasaan BN seperti Pulau Pinang, Kedah, Selangor, Perak (sebelum diambil semula oleh BN pada 2009) dan mengekalkan Kelantan. Pencapaian pakatan pembangkang ini adalah luar biasa memandangkan baru pertama kali dalam sejarah politik Malaysia sejak merdeka, BN gagal memperoleh kerusi 2/3 parlimen. Menarik daripada kejayaan PAS dalam pilihan raya 2008 ini adalah wujudnya sokongan daripada pengundi bukan Islam yang cukup besar sehingga menyebabkan kemenangan PAS. Sekalipun faktor-faktor lain dilihat mempengaruhi keputusan pengundi seperti muak dengan kerajaan $\mathrm{BN}$, isu gejala rasuah dan sabotaj di dalam UMNO, tidak diragukan lagi, unsur terpenting daripada kemenangan PAS adalah wujudnya imej baru PAS yang lebih moderat, bertolak ansur, lebih terbuka dan progresif. PAS berjaya mengitar semula (rebranding) wajahnya daripada parti yang ortodok dan kaku menuju PAS yang baru. Oleh itu, muncul slogan baru yang dicanang PAS seperti 'PAS for All', 'Keadilan untuk 
Semua' bagi menggambarkan perubahan pendekatan dan imej PAS yang baru..$^{64}$

Ketiga, kewujudan Pakatan Rakyat (PR). Kejayaan barisan pembangkang dalam pilihan raya 2008 membawa kepada perpaduan dan kerjasama di pihak pembangkang dengan menubuhkan PR. Selain PAS, pakatan pembangkang ini terdiri daripada DAP, parti yang didominasi oleh kaum Cina dan Parti Keadilan Rakyat (PKR), parti yang berasaskan multietnik. Kerjasama dan persefahaman politik di antara parti komponen pembangkang itu diterjemahkan dalam buku jingga yang mengandungi manifesto, dasar bersama dan program PR jika mereka memerintah negara. ${ }^{65}$ PAS berhujah bahawa kerjasama politik dengan orang bukan Islam di dalam PR adalah sebahagian daripada amalan tahaluf siyasi sebagaimana yang diamalkan oleh Nabi Muhammad ketika berdepan dengan kaum musyrik. Sekali lagi, negara Islam tidak menjadi tawaran PAS dalam proses rundingan mereka dengan rakan politiknya dan menggugurkan agenda itu demi terciptanya kerjasama yang kukuh dan padu bagi merealisasikan objektif menawan Putrajaya. ${ }^{66}$ Sebaliknya, PR menegaskan kedudukan Islam sebagai agama rasmi negara dan menjamin hak kebebasan beragama bagi semua rakyat Malaysia. ${ }^{67}$ Ini bermakna, pemahaman ini sama sebagaimana yang difahami oleh pemerintahan sekarang yang dulu menjadi bahan utama PAS untuk menyerang UMNO yang dianggap tidak memperjuangkan Islam disebabkan pemahaman dan amalan yang sedemikan.

Keempat, dominasi golongan Erdogan. Proses penyahan ideologi negara Islam yang disebabkan faktor dalaman PAS ditandai dengan kemunculan dan dominasi kumpulan 'Erdogan'68 dalam struktur jawatankuasa PAS pusat. ${ }^{69}$ Kumpulan yang berkait rapat dengan Anwar Ibrahim ini dikatakan sangat mempengaruhi dasar dan program PAS terutama yang berkaitan dengan idea bagaimana PAS merubah parti yang cenderung berfikiran tradisional dan konservatif ke arah parti yang progresif dan pragmatikal terutama ketika berdepan dengan percaturan politik yang begitu dinamik. ${ }^{70}$ Kumpulan ini juga yang dikatakan berpengaruh besar dalam merubah strategi pendekatan politik PAS, daripada memperjuangkan negara Islam kepada negara berkebajikan yang dipertikaikan oleh sesetengah pimpinan PAS itu sendiri. ${ }^{71}$

Dalam konteks Indonesia, pasca tumbangnya rejim Orde Baru, penyahan ideologi negara Islam nampaknya bertukar corak dan rentak. Jika pada era Orde Baru, penyahan ideologi banyak ditentukan oleh faktor luaran, pada era reformasi berlaku sebaliknya. Apa yang menarik dalam proses perubahan idea negara Islam di Indonesia adalah apabila berlakunya peristiwa reformasi pada 1998 yang ditandai dengan terbukanya pintu kebebasan dan terciptanya demokrasi. Tidak 
sebagaimana yang berlaku pada era sebelum reformasi, di mana Islam politik dianggap sebagai musuh utama yang perlu dilumpuhkan kekuatannya dan isu negara Islam adalah isu yang diharamkan sebagai wacana politik, sebaliknya pada era reformasi, gagasan dan idea apapun menjadi isu yang tiada batasan dan semua isu boleh dibincang. Semua unsur dan komponen bangsa mengalami euforia kebebasan bersuara mahupun berekspresi setelah sekian lama dicengkam di bawah pemerintahan autoritarian. Wacana politik dipenuhi semula dengan berbagai-bagai isu seperti ideologi politik, aliran keagamaan bahkan aliran sosialis yang sebelumnya menjadi perkara yang sensitif dan diharamkan, kembali giat diperkatakan dan diperjuangkan oleh masing-masing pihak. Walhal, ini termasuklah idea negara Islam yang turut diperjuangkan oleh beberapa parti politik yang bertanding dalam pilihan raya pasca reformasi pada tahun 1999 yang mencecah 35 parti. ${ }^{72}$

Keputusan pilihan raya pada 1999 yang dikatakan paling demokratik di Indonesia setelah pilihan raya pertama pada tahun 1955, mengecewakan parti Islam. Pada pilihan raya itu, jumlah undi untuk seluruh parti politik Islam hanya meraih undi 35 peratus bersamaan dengan meraih 171 kerusi daripada 462 kerusi yang dipertandingkan. ${ }^{73}$ Diawali dengan perasaan optimisme yang cukup tinggi akan kejayaan meraih undi daripada umat Islam yang merupakan 85 peratus daripada penduduk Indonesia, parti-parti politik Islam harus menerima kenyataan pahit bahawa mereka tewas dan tidak meraih sokongan yang mencukupi untuk merealisasikan impian menubuhkan negara Islam. Jumlah ini berkurang secara drastik menjadi 17 peratus sahaja sekiranya Partai Kebangkitan Bangsa (PKB) dan Partai Amanat Nasional (PAN) tidak diiktiraf sebagai parti Islam. Meskipun pengundi PKB dan PAN itu berasal daripada pengundi umat Islam yang berada di NU dan Muhammmadiyah, akan tetapi kedua parti itu menolak berdirinya negara Islam. ${ }^{74}$

Salah satu parti Islam di Indonesia yang dianggap fenomena pasca reformasi adalah Partai Keadilan Sejahtera (PKS). ${ }^{75}$ Parti yang diasaskan oleh aktivis tarbiyah dan gerakan mahasiswa Islam di kampus ini mampu menjelma menjadi parti Islam yang paling kuat mengatasi partiparti Islam lain yang terlebih dahulu lahir dan bertapak kukuh dalam kalangan umat Islam. ${ }^{76}$ Sebagai parti yang banyak diinspirasikan oleh model dan gerakan Ikhwanul Muslimin, pada peringkat awal parti ini banyak memfokuskan kepada agenda dan misi yang berkaitan dengan Islam sebagai sistem, ideologi dan asas kepada pelaksanaan pentadbiran negara. Oleh itu, pada kemunculan pertama kali pada pilihan raya 1999, PKS mengangkat isu dan agenda utama yang diperjuangkan berkisar kepada pelaksanaan syariat Islam, hukum Islam dan penubuhan negara Islam. ${ }^{77}$ 
PKS percaya dengan menguasai pusat kekuasaan dan kepimpinan tertinggi negara, pelaksanaan idea dan agenda parti akan mudah dilaksanakan. Ringkasnya, platform dan isu yang menjadi isu utama PKS dalam menghadapi pilihan raya tidak lari daripada isu-isu yang menjadi ciri utama gerakan Islam yang lain. Dengan menonjolkan supremasi Islam sebagai satu-satunya kekuatan yang mempunyai matlamat Islam sebagai penyelesai (al-Islam huwa al hall), Islam sebagai alternatif (al-Islam ka badil) dan Islam sebagai sistem pemerintahan (nizam al-Islami).

Dengan menggunakan strategi menjanjikan penerapan syariat Islam dan mengkempenkan sistem Islam sebagai solusi atas pelbagai krisis multidimensi yang dihadapi Indonesia ketika itu, PKS percaya akan memperolehi undi yang besar daripada umat Islam di Indonesia pada pilihan raya tahun 1999. Nada optimis memperoleh undi besar, selain berasaskan kepada realiti bahawa Islam merupakan pengundi terbesar, ia juga diasaskan kepada kekuatan PKS yang mempunyai jaringan dan sel-sel yang tersusun secara sistematik terhasil daripada aktiviti tarbiyah yang selama ini terbina secara rapi. Akan tetapi, faktanya tidak demikian. Asas penyokong PKS yang banyak terdapat di kampus-kampus dan kalangan Islam bandar, ternyata tidak seramai yang disangka dan tidak banyak membantu menambah undi parti. Sebaliknya, PKS memperoleh keputusan di luar jangkaan dengan hanya memperoleh undi 1.36 peratus suara atau 7 kerusi parlimen. ${ }^{78}$

Berdasarkan keputusan dan hasil yang cukup mengecewakan itu, PKS kemudian merubah pendekatan dan strategi politiknya dalam menghadapi pilihan raya berikutnya. Jika pada pilihan raya 1999 PKS banyak mengangkat tema-tema eksklusif (Islamis) dan seolah-olah hanya dihalakan dalam kalangan sendiri, pada pilihan raya 2004, PKS banyak mengembangkan isu nilai-nilai universal seperti pernyataan perang kepada rasuah, cara pemerintah yang baik (good governance), isu kebajikan rakyat dan kesejahteraan ekonomi. ${ }^{79}$ Jika sebelumnya, PKS (dan parti-parti Islam yang lain) lebih banyak memainkan simbol, isu keislaman dan yang bersifat ideologis lainnya bagi memperoleh sokongan dan undi rakyat, pada pilihan raya 2004, PKS terus menyentuh kepada persoalan-persoalan rakyat dan membuat programprogram yang nyata dalam menyelesaikan masalah rakyat. ${ }^{80}$ Dengan tagline 'bersih dan peduli', PKS juga dilihat tidak lagi terperangkap dengan isu-isu eksklusif dan menghindari secara terang-terangan isu-isu yang sensitif seperti penerapan syariat, hukum Islam atau negara Islam. Nampaknya PKS menyedari bahawa undi yang diperoleh pada pilihan raya 1999 hanya berasal daripada ahli dan kadernya yang berpusat di kawasan kampus-kampus dan kawasan bandar. ${ }^{81}$ 
Oleh itu, untuk memperoleh sokongan yang lebih meluas dan dapat diterima oleh semua kalangan khususnya daripada pengundi berorientasi nasionalis, PKS tidak lagi memperjuangkan implementasi syariat sebagai manifesto utamanya. Dengan mengenepikan pelaksanaan syariat Islam dan sebaliknya lebih mengangkat isu-isu yang sifatnya universal, PKS dapat dilihat mewakili semua aspirasi masyarakat Indonesia yang majoritinya tidak melihat angkubah sentimen agama sebagai dasar untuk mengundi sesebuah parti. Sebaliknya, rakyat Indonesia melihat dan menilai parti berdasarkan kepada seberapa besar komitmennya kepada pembanterasan rasuah, komitmen kepada peningkatan kesejahteraan ekonomi rakyat, komitmen kepada penegakan hukum yang mesti dituntaskan penyelesaiannya. ${ }^{82}$

Kemuncak proses perubahan ideologi negara Islam secara dalaman berlaku ketika PKS mengisytiharkan dirinya sebagai parti terbuka. ${ }^{83}$ Akibat yang ditimbulkan daripada pengisytiharaan ini, beberapa perkara yang selama ini sinonim pada PKS dan menjadi titik pembeza dengan parti lain turut mengalami perubahan dan penyahan. Dengan menjadi parti terbuka, PKS telah menyingkirkan perkara-perkara yang selama ini menjadi hak eksklusif parti seperti asas parti, platform parti, anggota parti, ahli jawatan kuasa parti dan calon yang bertanding dalam pilihan raya. Jika sebelumnya kesemua hak itu diberikan kepada ahli parti yang beragama Islam sahaja, dengan menjadi parti terbuka, orang bukan Islam pun berhak menjadi bahagian penting parti. ${ }^{84}$

Perubahan ini termasuk penyesuaian PKS terhadap asas dan platform parti yang mana selama ini PKS begitu sinonim sebagai parti Islam yang memperjuangkan pelaksanaan syariat Islam. PKS beranggapan agenda penerapan syariat Islam tidak relevan lagi ditetapkan sebagai agenda utama parti, bagi membolehkan parti memperoleh sokongan dan undi yang lebih luas. Selebihnya PKS berpandangan lebih mengutamakan agenda-agenda yang sifatnya lebih inklusif dan universal seperti pembanterasan rasuah dan salah laku kuasa. Perjuangan kepada agenda pembanterasan rasuah bagi PKS merupakan bahagian daripada manifestasi menegakkan amar ma'rufnahi munkar sebagaimana yang diwajibkan dalam syariah Islam itu sendiri. ${ }^{85}$

Pengisytiharan yang dibuat pada perhimpunan agung PKS pada Jun 2010 menunjukkan berlakunya revolusi pemikiran dan strategi politik PKS dalam menghadapi dinamika dan realiti politik di Indonesia. ${ }^{86}$ Tidak berbeza dengan apa yang berlaku pada PAS, perubahan yang berlaku dalam PKS dengan pengisytiharan parti terbuka itu menunjukkan wujudnya pertembungan pendekatan dan cara menangani parti di antara golongan ideologis-orthodoks ${ }^{87}$ vis a vis progresif-pragmatik. ${ }^{88}$ Golongan pertama merupakan kelompok ideologis yang tidak menginginkan PKS menjadi parti terbuka dan 
menghendaki parti tetap konsisten sebagai parti dakwah. Ini termasuk pendirian mereka yang menginginkan penerapan syariat Islam sebagai acuan utama parti yang tidak boleh ditawar lagi. Bagi golongan ideologis ini, mereka lebih redha dan ikhlas melihat parti tidak besar dan tidak mendapatkan sokongan yang lebih meluas asalkan matlamat asal sebagai parti yang memperjuangkan tegaknya negara yang berdasarkan syariat Islam tidak tergadaikan oleh kepentingan-kepentingan politik yang bersifat pragmatik. ${ }^{89}$

Kumpulan pragmatik-progresif pula berpandangan bahawa matlamat parti untuk mengislamisasikan sistem dan masyarakat Indonesia berdasarkan hukum Islam tidak akan dapat terlaksana seandainya suara parti tidak besar dan mencukupi. Oleh itu, diperlukan ijtihad politik dengan menjadikan PKS sebagai parti terbuka yang memungkinkan orang di luar ahli PKS tegar dan orang bukan Islam turut menyertai dan menyokong parti. Kubu pragmatik-progresif ini menginginkan PKS sebagai parti untuk semua rakyat Indonesia tanpa melihat latar belakang pengundi sama ada agama, etnik, peringkat pendidikan, jenis jantina, bandar-kampung, jenis pekerjaan dan kumpulan umur (catch-all party). ${ }^{90}$

Dalam hal ini, PKS menyedari bahawa rakyat Indonesia yang plural dan heterogen merupakan aset bangsa yang harus dihormati keberadaannya. Keputusan PKS ini juga dilihat sebagai langkah strategik bagi meraih sokongan dan undi di luar jamaah dan ahli PKS yang merupakan jumlah pengundi terbesar yang belum disentuh parti itu. Selari dengan pendirian itu, PKS tidak mementingkan lagi simbol dalam aspek perjuangannya akan tetapi lebih mementingkan isi dan kandungan. Dalam masalah isu negara Islam misalnya, PKS beranggapan Indonesia sudah dianggap sebagai negara Islam berdasarkan kepada peraturan, undang-undang, jumlah penduduknya dan fakta-fakta lain yang menunjukkan sejumlah prinsip-prinsip Islam diterapkan di dalam sistem dan hukum di Indonesia. Oleh sebab itu, PKS memberikan fokus kepada usaha untuk memperjuangkan dan melaksanakan dasar pemerintah berdasarkan syariat Islam tanpa harus mengisytiharkan secara formal Indonesia sebagai negara Islam. ${ }^{91}$

\section{Kesan Perubahan Ideologi}

Kedua-dua parti iaitu PAS dan PKS mengalami masalah yang sama dari segi strategi pendekatan politik khasnya yang berkaitan dengan Islam sebagai ideologi negara. Bagaimanapun, kedua-dua parti itu mengalami impak yang berbeza. Secara umum, perubahan isu negara Islam kepada negara berkebajikan yang dilancarkan PAS tidak terlalu memberi kesan yang mendalam sama ada di kalangan dalaman parti 
mahupun di kalangan ahlinya. Dalam kalangan pimpinan parti, perubahan ini disokong sepenuhnya oleh PAS sebagaimana yang telah diputuskan dalam Muktamar ke-57 pada Jun 2011. Bagi PAS, perubahan pendekatan ini merupakan satu pendekatan yang perlu diambil memandangkan sokongan di luar ahli khasnya di kalangan bukan Islam semakin meningkat. ${ }^{92}$

Walaupun sempat berlaku konflik dalaman berikutan kes pemecatan Hasan Ali sebagai Pesuruhjaya PAS Selangor pada 2012, PAS mengakui dan percaya bahawa kerjasama di antara manusia tanpa melihat perbezaan agama merupakan ketentuan Allah (sunnatullah) yang tidak boleh dielakkan. ${ }^{93}$ Ia menjadi sifat tabii manusia yang saling memerlukan dan tolong menolong bagi tujuan mendapatkan kebaikan dan kesejahteraan seluruh umat manusia secara keseluruhan. ${ }^{94}$ Oleh sebab itu, PAS perlu merubah pendekatannya secara praktikal dari negara Islam kepada negara berkebajikan. Perubahan ini penting agar persepsi terhadap PAS tidak lagi dilihat sebagai parti konservatif, kolot dan fundemantalis sebaliknya PAS boleh dilihat sebagai parti alternatif yang membawa harapan kepada terciptanya masyarakat madani dan persekitaran sistem sosio-politik yang lebih baik daripada UMNO. ${ }^{95}$

Tidak sebagaimana PAS, pengalaman PKS agak berbeza. Meskipun PKS tidak pernah secara terbuka menghendaki Indonesia sebagai negara Islam, akan tetapi perubahan strategi politik PKS kepada parti terbuka mencetuskan perbalahan di kalangan dalaman parti. Beberapa kalangan yang terdiri daripada ahli dan penyokong tradisi PKS yang berasal dari kem ideologis, menolak pendirian parti terbuka dan menyatakan meninggalkan parti kerana menganggap PKS telah terkeluar daripada manhaj parti dakwah berikutan perubahan kepada parti terbuka. ${ }^{96}$

Impak perubahan pendekatan PKS daripada memperjuangkan isuisu yang beraroma syariah (shariah minded) kepada isu dan perjuangan parti yang bersifat pragmatikal dan cenderung meminggirkan isu syariah dapat dilihat pada keputusan pilihan raya pada 2009. Beberapa kawasan yang dikenalpasti sebagai kubu kuat PKS pada pilihan raya 2004 seperti di Jakarta, Jawa Barat, Padang dan Maluku Utara mengalami penurunan undi yang cukup ketara. Namun pada masa yang sama, di daerah-daerah lain yang sebelumnya PKS sukar mendapatkan undi dan sokongan seperti di daerah Jawa Tengah, Jawa Timur dan Sulawesi Tengah terjadi peningkatan undi. ${ }^{97}$ Malah, dengan strategi parti terbuka, PKS berjaya menambah undi daripada pengundi bukan muslim dibanding pilihan raya sebelumnya. Secara kesuluruhan perolehan undi PKS mengalami peningkatan meskipun tidak drastik, dari 7,34 peratus kepada 8 peratus yang menjadikan PKS sebagai parti Islam terbesar hari ini. ${ }^{98}$ 
Perkembangan yang berlaku pada parti politik Islam ini khasnya mengenai idea negara Islam menunjukkan berlakunya situasi politik yang dinamik. Ini tentu sudah menjadi hukum tabii dunia politik yang selalu berkembang dan tidak statik dalam menghadapi realiti yang berlaku di masyarakat sebagai pemegang kuasa untuk menentukan sistem dan bentuk sesebuah kerajaan. Parti politik sebagai institusi yang mewakili pandangan dan aspirasi sesebuah masyarakat akan mengikuti kehendak dan sentimen rakyat yang akan diwakilinya. Simbolisme, meskipun penting, tidak akan bermakna seandainya dalam praktiknya tidak mencerminkan amalan yang sesungguhnya terhadap simbol tersebut. ${ }^{99}$

Apa yang menarik dalam isu mengenai negara Islam kebelakangan ini adalah berlakunya perubahan dari segi pelaku dan tapak percaturan idea dan gagasan negara Islam. Jika sebelumnya parti politik dianggap sebagai institusi yang paling sesuai dan realistik dalam memperjuangkan impian penubuhan negara Islam, mutakhir ini situasi mula berubah. Peranan itu sekarang diambil alih oleh pertubuhan-pertubuhan bukan kerajaan dan khususnya di kalangan pertubuhan yang berspektrum transnasional seperti Hizbut Tahrir, gerakan Salafi, kumpulan Islam radikal dan beberapa organisasi tempatan. ${ }^{100}$

Mereka melihat parti politik Islam dewasa ini sudah tidak layak diharapkan peranannya kerana parti politik Islam sudah terjebak dengan pragmatisme politik sehingga meminggirkan cita-cita penubuhan negara Islam. Namun sayangnya, ada sesetengah gerakan Islam ini menempuh kaedah yang salah dalam kaedah perjuangannya dengan menggunakan cara kekerasan untuk merealisasikan matlamat politik mereka. Malah, Hizbut Tahrir menolak sistem demokrasi dan pilihan raya sebagai mekanisme untuk mencipta sistem politik dan perlembagaan yang paling ideal bagi sesebuah masyarakat. Walhal, sesungguhnya dengan sistem demokrasi juga lah yang memungkinkan mereka dapat hidup dan berkembang memperjuangkan idealisme dan cita-cita mereka.

\section{Kesimpulan}

Daripada perbincangan yang telah dihuraikan dapatlah diambil rumusan bahawa gagasan dan idea negara Islam mengalami perkembangan yang begitu dinamik dan terus menjadi tumpuan kepada aktivis dan kalangan akademik untuk membincangkannya. Secara umumnya dapat dilihat bahawa isu negara Islam sebagaimana yang dikonsepsikan oleh sebahagian besar kalangan Islamis yang menekankan dimensi formalisme hukum agama dalam sistem kenegaraan dewasa ini menunjukkan pertanda kepada hujung noktahnya. Dalam kalangan 
Islamis sama ada daripada aktivis parti politik mahupun bukan parti politik telah memberikan gambaran secara jelas bahawa idea negara Islam perlu dirumus semula agar ia bersesuaian dengan konteks semasa. Realiti yang berkembang termasuk apa yang berlaku di dunia Islam pada amnya dewasa ini turut menghala pada fenomena yang sama.

Dari pemerhatian yang mendalam terhadap fenomena ini, dapat diambil kesimpulan bahawa isu-isu yang diperjuangkan oleh parti politik Islam tidak lagi menjadikan idea negara Islam dan elemenelemen lain sebagai ciri khasnya dalam platform utama parti. Mereka mula menekankan isi dan kandungan sebuah agenda dan program berbanding kepada bentuk formal agama. Sebaliknya, isu-isu universal dan'sekular' yang menjadi nilai-nilai murni semua agama telah berjaya melangkaui isu eksklusif sesebuah agama dan seterusnya menjadikan isu itu sebagai agenda parti politik Islam. Isu seperti perang terhadap rasuah, pembanterasan unsur nepotisme dalam mengisi jawatan awam, tidak bertolak ansur kepada amalan pecah amanah, menciptakan pemerintahan yang bersih dan urus tadbir yang baik, mengsejahterakan dan memakmurkan rakyat, membela golongan minoriti, penghormatan kepada kepelbagaian agama dan etnik, pembelaaan kepada hak asasi manusia dan isu-isu lain yang selama ini seolah-olah hanya diperjuangkan parti politik nasionalis-sekularis turut menjadi fokus dan perhatian parti politik Islam.

Perkara ini berlaku secara ketara sebagaimana yang ditonjolkan oleh PAS dan PKS. Kedua-dua parti politik itu mentransformasikan dirinya sebagai parti yang sebelumnya cenderung eksklusif kepada parti yang progresif-realistik-pragmatik bagi menyesuaikan diri kepada persekitaran politik yang menuntutnya demikian. Boleh dikatakan rakyat di Malaysia dan Indonesia tidak lagi terperangkap dengan simbolisme agama semata-mata bagi menyatakan dukungan kepada parti politik tertentu. Apa yang lebih penting adalah bagaiamana parti politik itu mempunyai komitmen yang tinggi dalam merealisasikan program serta menepati kehendak dan citarasa rakyat.

\section{Nota}

Pandangan tentang kewajipan muslim untuk mendirikan negara Islam yang banyak dianut oleh aktivis Islam banyak diinspirasikan oleh pemikiran politik Hasan Al Banna, pengasas Ikhwanul Muslimin. Menurut Hasan Al Banna, menguasai arena politik yang berdimensi syariat Islam (siyasah syar'iyyah) merupakan rukun Islam. Ini bermakna, setiap muslim yang tidak menyokong perjuangan berdirinya negara Islam atau pemimpin negara tidak menerapkan hukum Islam dalam sistem pemerintahannya, dianggap berdosa. Keterangan lanjut tentang pemikiran politik Hasan Al Banna, lihat Hasan Al Banna, Majmuatur 
Rasail, Kumpulan Risalah Dakwah Hasan Al Banna, Jilid 2, (terj.), Solo: Era Intermedia, 2008, hlm. 69-71.

2 Fenomena tentang berlakunya pertembungan ideologis antara golongan Islamis dan golongan nasionalis ini nampaknya tidak hanya berlaku di Malaysia dan Indonesia saja. Di Mesir misalnya, konflik ideologis ini menjadi salah satu faktor munculnya pergerakan Ikhwanul Muslimin yang menghendaki wujudnya pemerintahan Islam yang menerapkan prinsip syariat Islam dalam sistem hukum dan dalam perlembagaan negara. Begitu juga halnya di negara-negara lain di kawasan Timur Tengah yang kebanyakannya tidak menerapkan prinsip Islam secara sepenuhnya sebagaimana yang menjadi ciri utama dari idealisme negara Islam yang dikonsepsikan oleh aktivis Islam. Di dunia Islam, tercatat hanya segelintir negara yang menerapkan hukum hudud dan syariat Islam secara ketat seperti Arab Saudi, Iran dan Pakistan. Lihat Sangwon Suh dan Santha Oorjitham, Battle for Islam: UMNO and Pas are Locked in a Struggle for the Malay Soul, The Outcome may Irrevocably Change Malaysian Society, Asiaweek, 16 Jun 2000. Ibrahim Ahmad, Konflik UMNO-PAS dalam Isu Islamisasi, Petaling Jaya: IBS Buku Sdn Bhd, 1989, hlm. 51-66.

5 Joseph Chinyong Liow, Political Islam in Malaysia: Problematising Discourse and Practice in the UMNO-PAS 'Islamisation Race', dalam Joseph Chinyong Liow dan Nadirsyah Hosen, Islam in Southeast Asia: Critical Concepts in Islamic Studies Volume II, London and New York: Routledge, 2010, hlm. 134-154.

6 Mohamad Abu Bakar, Polemik Negara Islam dan Pembudayaan Politik Malaysia, Petaling Jaya: Institut Perkembangan Minda (INMIND), 2002, hlm. 1.

7 Dalam sebuah buku kecil yang dikeluarkan oleh salah satu agensi kerajaan, Malaysia sudah dianggap sebagai negara Islam disebabkan fakta-fakta berikut: 1. Ketua kerajaan adalah muslim, 2. Islam merupakan agama rasmi negara, 3. pentadbiran negara berasaskan sistem syura berparlimen, 4. telah melaksanakan peraturan dan undang-undang berasaskan prinsip Islam seperti hukum bunuh bagi pembunuh, takzir bagi pezina atau mencuri 5. undang-undang di Malaysia juga diamalkan di negara-negara Islam yang lain, 6. Malaysia adalah pemimpin negara Islam dalam dunia perniagaan dan perdagangan, 7. Malaysia telah diiktiraf sebagai negara Islam oleh Syekh Al Azhar, Mohammad Sayed Tantawi dan beberapa ulama dunia yang lain, 8 . setiap muslim bebas menjalankan ibadah dan prasarana yang mencukupi, 9. prinsip Islam menjadi teras kepada sistem pendidikan dan perancangan politik. Lihat, Abd Manaf bin Hj Ahmad, Negara Islam: Satu Analisa Perbandingan, Kuala Lumpur: Yayasan Dakwah Islamiyah Malaysia, 2004, hlm. 91.

8 Wawancara dengan Mahathir Mohamad, Mantan Perdana Menteri Malaysia ke-4, di Menara KLCC Kuala Lumpur, 18 Mei 2010.

9 Lihat Farish A. Noor, Blood, Sweat and Jihad: The Radicalization of the Political Discourse of the Pan-Malaysian Islamic Party (PAS) from 1982 onwards, dalam Joseph Chinyong Liow dan Nadirsyah Hosen, Islam in 
Southeast Asia: Critical Concepts in Islamic Studies Volume II, London and New York: Routledge, 2010, hlm. 82-83.

10 Lihat Syed Ibrahim Syed Noh, ISA is Against Islam. Aliran Monthly, Vol. 24, No. 8, 2004.

11 Pandangan Yusuf Rawa, Presiden PAS 1982-1990, dipetik dalam Hussin Mutalib, Islam in Malaysia: From Revivalism to Islamic State, Singapore: National University of Singapore, 1993, hlm. 99.

12 Bahawa UMNO sebati dengan Islam dapat dilihat daripada simbol huruf a, ba, ta dalam logo UMNO dan singkatan UMNO itu sendiri yang sebahagiannya diterjemahkan sebagai ugama (baca Islam), Melayu, Nasional dan organisasi. Oleh sebab itu, dengan sendirinya Islam tidak dapat dipisahkan daripada UMNO. Perbincangan peribadi dengan Abdullah Zakaria, Profesor di Jabatan Sejarah Universiti Malaya, Kuala Lumpur 5 Julai 2011.

$13 \quad 17$ Ramadhan, Pas Lancar Konsep Negara Islam, http:/ / subkylatif.blogspot.com/2003/10/17-ramadhan-pas-lancarkonsep-negara.html (diakses 8 April 2012).

14 Perbincangan lanjut tentang persatuan Islam di bawah bendera Masyumi, lihat Harry J. Benda, The Crescent and the Rising Sun: Indonesian Islam under the Japanese Occupation 1942 - 1945, The Hague dan Bandung: W.Van Hoeve Ltd, 1958.

$15 \quad$ Karya terbaik yang membicarakan tentang pilihan raya 1955, lihat Herbert Feith, The Decline of Constitutional Democracy in Indonesia, Ithaca: Cornell University Press, 1964.

16 M. Rusli Karim, Negara dan Peminggiran Islam Politik, Yogyakarta: Tiara Wacana, 1999.

17 Lihat kajian Syamsuddin Haris, PPP dan Politik Orde Baru, Jakarta: Grasindo, 1991.

18 John Funston, Malay Politics in Malaysia: A Study of UMNO and PAS, Petaling Jaya: Heinemann Educational Books, 1980, hlm. 93.

19 Kajian tentang pertembungan ideologi kebangsaan dan keislaman di Malaysia, lihat Hussin Mutalib, Islam dan Etnisitas: Perspektif Politik Melayu, (terj. A.E. Priyono), Jakarta: LP3ES, 1995.

20 Islamisasi dalam wilayah pentadbiran dikenali menerusi Dasar Penerapan Nilai-Nilai Islam. Slogan Bersih, Cekap, Amanah dan Kepimpinan Melalui Teladan. Lihat Azali Bin Atan, Islam, Politik dan Pentadbiran: Satu Tinjauan mengenai Proses Penerapan Nilai-nilai Islam di Malaysia, Latihan Ilmiah, Jabatan Sains Politik, Fakulti Sains Sosial dan Kemanusiaan, UKM, 1986.

21 Salah satu aspek penting dalam Islamisasi di bidang kehakiman dan undang-undang adalah dengan adanya kedudukan dan taraf yang sama di antara mahkamah sivil dan mahkamah syariah pada tahun 1985. Dengan menaiktaraf mahkamah syariah, umat Islam mempunyai sistem perundangan tersendiri berdasarkan syariat Islam. Lihat, Mahmud Saedon A. Othman, Institusi Pentadbiran Undang-Undang dan Kehakiman Islam, Kuala Lumpur: Dewan Bahasa dan Pustaka, 1998. Kritik tentang dualisme sistem kehakiman ini, lihat Norani Othman, Islamisasi dan 
Demokrasi di Malaysia dalam Konteks Regional dan Global, dalam Ariel Haryanto dan Sumit K. Mandal (pnyt), Menggugat Otoriterisme di Asia Tenggara: Perbandingan dan Pertautan antara Indonesia dan Malaysia, Jakarta: Gramedia, 2004, hlm. 258-262.

Beberapa produk yang terhasil daripada dasar Islamisasi dalam bidang ekonomi adalah penubuhan Bank Islam, insurans Islam (takaful), sistem gadai Islam (arrahn). Malaysia juga dikenali sebagai pusat hub halal di rantau Asia Tenggara di mana Malaysia antara negara terawal yang mempelopori sijil halal. Pada awal tahun 1993, sebanyak 21 produk bank Islam telah berjaya diwujudkan, antaranya adalah al-wadiah, almudharabah, al-musyarakah, al-murabahah, al-bai bithaman ajil, baiul salam, al ijarah, al-bai al-ta'jiri, al-wakalah, al-rahn, al-qardhul hasan, dan al-kafalah. Pada penghujung tahun 1993, sistem perbankan Islam di Malaysia sudah mengandungi sebuah bank Islam dan 20 buah institusi kewangan yang terdiri dari 10 buah bank perdagangan, lapan buah syarikat kewangan dan dua syarikat saudagar yang menawarkan perkhidmatan dan produk berdasarkan prinsip Islam. Lihat, Pembangunan Islam di Malaysia, http://www.islam.gov.my/e-rujukan/islammas.html (diakses 10 Jun 2008).

Kerajaan telah menggubal Kurikulum Baru Sekolah Rendah (KBSR) dan Kurikulum Bersepadu Sekolah Menengah (KBSM) yang menjadi tunjang kepada pendidikan pra universiti. Kurikulum baru ini dilihat sebagai pengislaman kurikulum sekolah memandangkan banyak pelajaran agama yang diajarkan. Dibuka juga Sekolah-sekolah Menengah Kebangsaan Agama (SMKA) yang mencecah 40 buah dan kelas-kelas aliran agama diperkenalkan di lebih 200 buah sekolah Menengah Kebangsaan di seluruh negara. Perkembangan pendidikan Islam semakin rancak dengan lahirnya beberapa universiti-universiti dan kolej-kolej Islam yang diasaskan oleh pihak swasta dan beberapa kerajaan negeri yang disokong penuh oleh kerajaan pusat. Bagaimanapun, kemuncak daripada simbolisme pendidikan Islam adalah dengan penubuhan Universiti Islam Antarabangsa (UIA) pada 11 Mei 1983. JAKIM, Pembangunan Islam di Malaysia, http://www.islam.gov.my/e-rujukan/islammas.html, (diakses 10 Jun 2008).

Terence Chong, The Emerging Politics of Islam Hadhari, dalam Saw Swee Hock dan K. Kesavapany (pnyt), Malaysia: Recent Trends and Challenges, Singapore: ISEAS, 2006, hlm. 26-46.

Khadijah Md. Khalid, Voting for change? Islam and Personalized Politics in the 2004 General Elections, dalam Terence Gomez, Edmund, (pnyt), Politics in Malaysia: The Malay Dimension, London: Routledge, 2007, hlm. 138.

26 Dekrit Presiden adalah satu keputusan politik yang dikeluarkan oleh Presiden Soekarno untuk membubarkan Majlis Konstituante (Parlimen) setelah berlakunya perdebatan yang tiada penghujung di antara kem Islam yang menghendaki Piagam Jakarta dimasukkan dalam perlembagaan yang menjurus ke arah negara Islam dan kem nasionalis yang menghendaki Pancasila sebagai ideologi nasional. Perdebatan dan pertentangan di 
antara dua kem itu sendiri telah memakan masa 2 tahun 5 bulan dan 12 hari. Keadaan ini berlaku setelah pilihan raya pertama pada 1955 yang menyaksikan tiada parti politik yang dominan yang memperoleh kerusi $2 / 3$ yang boleh menggubal atau meminda perlembagaan. Oleh kerana dianggap membahayakan persatuan dan kesatuan bangsa, Soekarno menguatkuasakan dekrit bagi mengelakkan perpecahan di antara komponen bangsa yang diakibatkan oleh pertembungan menentukan ideologi negara. Lihat Boland, Pergumulan, hlm. 104-05. Piagam Jakarta (Jakarta Charter) adalah draf pembukaan Perlembagaan yang akan menjadi intipati daripada keseluruhan Undang-Undang Dasar Indonesia (perlembagaan) yang dibuat pada 22 Jun 1945. Apa yang dimaksudkan dengan Piagam Jakarta, yang kemudian menjadi kontroversi itu, adalah teks ayat yang terdiri daripada tujuh frasa yang berbunyi "dengan kewajiban menjalankan syariat Islam bagi pemelukpemeluknya". Pada awalnya, panitia persiapan kemerdekaan menyetujui bunyi teks itu. Akan tetapi, disebabkan adanya ancaman perpecahan dan pemisahan daripada wilayah Timur Indonesia yang majoritinya berpenduduk Kristian jika Piagam itu digubal, tujuh frasa yang terdapat dalam Piagam Jakarta tersebut dihapus. Oleh golongan Islam, Piagam Jakarta diperjuangkan untuk digubal kembali dalam sidang Konstituante yang kemudian menemui jalan buntu akibat penentangan daripada golongan nasionalis-sekularis. Kajian tentang perjuangan Piagam Jakarta, lihat Endang Saifuddin Anshari, Piagam Jakarta 22 Juni 1945 dan Sejarah Konsensus Nasional antara Nasionalis Islamic dan Nasionalis Sekular Tentang Dasar Negara Republik Indonesia 1945-1959, Bandung: Penerbit Pustaka, 1981.

28 Lihat Hamid Basyaib dan Hamid Abidin (pnyt), Mengapa Partai Islam Kalah? Perjalanan Politik Islam dari Pra-Pemilu'99 sampai Pemilihan Presiden, Jakarta: Alvabet, 1999.

29 Tentang proses peneriman Pancasila oleh kalangan Islam sebagai satusatunya asas atau ideologi negara lihat, Faisal Ismail, Islam and Pancasila: Indonesian Politics 1945 - 1995, Jakarta: Badan Litbang Agama dan Diklat Keagamaan Departemen Agama Indonesia, 2001.

30 Lihat Amin Fadlillah, Arus Perdana Islam di Malaysia dan Indonesia: Perspektif Sosio-Politik, Kertas Kerja yang dibentangkan dalam Persidangan Hubungan Malaysia - Indonesia ke-5 yang dianjurkan oleh Fakulti Sastera dan Sains Sosial, Universiti Malaya, 12-13 Julai 2011.

31 Nama-nama lain yang berada di barisan hadapan dalam kumpulan ini adalah Abdurrahman Wahid, Munawir Syadzali, Ahmad Wahib dan Johan Efendi. Rujuk beberapa karya yang sudah menjadi rujukan wajib dalam mengetahui proses pembaharuan Islam yang menjadi pencetus kepada perubahan konsepsi negara Islam di Indonesia seperti Fachry Ali dan Bahtiar Effendy, Merambah Jalan Baru Islam: Rekontruksi Pemikiran Islam Indonesia Masa Orde Baru, Bandung: Penerbit Mizan, 1986. Greg Barton, Gagasan Islam Liberal di Indonesia: Pemikiran Neo-Modernisme Nurcholish Madjid, Djohan Effendi, Ahmad Wahib dan Abdurrahman Wahid, (terj.), Jakarta: Paramadina, 1999. Untuk kajian yang kritikal terhadap fenomena ini lihat, 
Mohammad Kamal Hasan, Muslim Intellectual Responses to New Order Modernization in Indonesia, Kuala Lumpur: Dewan Bahasa dan Pustaka, 1980.

32 Keterangan lanjut lihat Azyumardi Azra, Islam dan Negara: Eksperimen dalam Masa Modern: Tinjauan Sosio-Historis, Ulumul Qur'an, No. 2, Vol. IV, 1993.

33 Syafi'i Anwar, Pemikiran dan Aksi Islam Indonesia: Sebuah Kajian tentang Cendekiawan Muslim Orde Baru, Jakarta: Penerbit Paramadina, 1995, bab 2.

34 Nurchlolish Madjid, Islam, Kemodernan dan Keindonesiaan, Bandung: Penerbit Mizan, 1972.

35 Nurcholish Madjid, Islam Doktrin dan Peradaban, Jakarta: Dian Rakyat dan Paramdina, 2008, cet. Ke-VI, hlm. 551.

36 Lihat, Fachry Ali dan Bahtiar Effendy, Merambah Jalan Baru Islam: Rekontruksi Pemikiran Islam Indonesia Masa Orde Baru, Bandung: Penerbit Mizan, 1986.

37 Lihat Nasir Tamara, Indonesia in the Wake of Islam: 1965 - 1985, Kuala Lumpur: Institute of Strategic and International Studies, 1986.

Bagi Soeharto, Masyumi masih dianggap berbahaya dan masih memiliki ramai pengikut. Namun demikian, Soeharto tidak mahu dianggap kuku besi dengan mengharamkan sama sekali aktiviti politik bekas tokoh Masyumi. Soeharto mengizinkan tokoh Masyumi mengasaskan parti dengan syarat tidak boleh menggunakan nama Masyumi sebagai nama parti politik dan tokoh-tokoh utama Masyumi seperti M. Nasir, Hamka, Mohammad Roem tidak boleh memegang jawatan utama dalam parti. Kemudian, berdirilah Partai Muslimin Indonesia (Parmusi) yang diterajui oleh S. Mintaredja (bekas Presiden Himpunan Mahasiswa Islam Indonesia pada era 1950-an).

39 Diskusi tentang strategi rejim Orde Baru bagi menyatukan parti politik Islam, lihat Syamsuddin Haris, PPP dan Politik Orde Baru, Jakarta: Grasindo, 1991.

$40 \quad$ Kes ini telah mengorbankan ratusan nyawa yang melayang akibat ditembak tentera ketika mereka berdemonstrasi menentang tentera yang tidak menghormati surau sebagai tempat ibadah. Hakikatnya aksi penentangan ini merupakan penumpukan rasa tidak puas hati umat Islam di kawasan Tanjung Priok yang tidak bersetuju kepada dasar kerajaan yang menjadikan Pancasila sebagai satu-satunya asas dan ideologi negara. Analisis lanjut tentang peristiwa ini lihat, Francois Raillon, The New Order and Islam or the Imbroglio of Faith and Politics, Indonesia, No. 57, April 1993, hlm. 197-217.

41 Sebelum melakukan rampasan kapal terbang Garuda laluan JakartaPalembang, jamaah yang dipimpin Imran ini menyerang balai polis di daerah Cicendo Bandung pada 11 Mac 1981 dan membunuh empat polis serta merampas senjata yang digunakan dalam rampasan kapal terbang itu. Lihat, Dari Syak Wasangka dan Sengketa, Tempo, 6 Julai 1991.

$42 \quad$ Warsidi merupakan seorang pimpinan pesantren di Desa Cihideung Lampung Tengah. Bersama murid-muridnya yang berjumlah 300 orang, 
Warsidi bercita-cita mendirikan negara Islam. Pendirian radikal mereka telah membawa korban seorang askar berpangkat kapten yang terbunuh oleh kelompok ini pada 6 Februari 1989. Akibatnya, pihak berkuasa menyerbu pesantren ini yang menyaksikan Warsidi turut terbunuh. Jumlah keseluruhan mangsa daripada kedua belah pihak tidak diketahui secara pasti. Ibid.

Faisal Ismail, Islam and Pancasila: Indonesian Politics 1945 - 1995, Jakarta: Badan Litbang Agama dan Diklat Keagamaan Departemen Agama Indonesia, 2001.

Lembaran Negara Republik Indonesia, Undang-Undang Republik Indonesia Nomor 8 Tahun 1985 tentang Organisasi Kemasyarakatan, Jakarta: Sekretariat Negara Republik Indonesia.

Mahathir Mohamad, Ucapan Perdana Menteri di Majlis Perasmian Persidangan Perwakilan ke-30 Parti Gerakan Rakyat Malaysia, Kuala Lumpur Sabtu 29 September 2001, Koleksi Arkib Negara.

Kikue Hamayotsu, "Islam and Nation Building in Southeast Asia: Malaysia and Indonesia in Comparative Perspective", Pacific Affairs, Volume 75, No. 3 - Fall 2002, hlm. 357-358.

Comroux, David, "State Responses To Islamic Resurgences In Malaysia: Accomadation, Co-option and Confrontation", Asian Survey, XXXVI (9), 1996.

Hamayotsu, Islam and Nation, hlm. 365.

Dalam konteks Malaysia, lihat Mujahid Yusof, Menuju PAS Baru: Krisis, Peluang dan Dinamisme, Kuala Lumpur: The Malaysian Insider, 2011. Dalam konteks Indonesia, lihat Burhanuddin Muhtadi, Dilema PKS: Suara dan Syariah, Jakarta: Kepustakaan Gramedia Popular, 2012. BN Rocked, New Sunday Times, 9 Mac 2008, Political Tsunami, The Star, 9 Mac 2008. It's Pakatan Rakyat, The Star, 2 April 2008. DAP Keluar Pakatan: Kegagalan Rundingan Isu Negara Islam dengan PAS Punca Tindakan, Mingguan Malaysia, 23 September 2001. John Funston, The Malay Electorate in 2004: Reversing the 1999 Result?, dalam Saw Swee- Hock dan K. Kesavapany, Malaysia Recent, Trends and Challenges, Singapura: Institute of Southeast Asian Studies, 2006, hlm. 132-156.

Ahmad Fauzi Abdul Hamid, The UMNO-PAS Struggle: Analysis of PAS's Defeat in 2004, dalam Saw Swee- Hock dan K. Kesavapany, Malaysia Recent, Trends and Challenges, Singapura: Institute of Southeast Asian Studies, 2006, hlm. 106.

Buku Konsep Negara Berkebajikan PAS Dilancar Hari Ini, laman sesawang, http:/ / www.themalaysianinsider.com/bahasa/article/bukukonsep-negara-berkebajikan-pas-dilancar-hari-ini/ (diakses 10 April 2012). Nik Aziz: Negara Kebajikan Selari dengan Islam, laman sesawang, http:/ / www.malaysiakini.com/news/166495, (diakses 10 April 2012). Malaysia, laman sesawang,http://presiden.pas.org.my/v2/index. 
php?option=com_content\&view $=$ article\&id=37:negara-berkebajikan-tawaran-pas-kepada-rakyat-malaysia-\&catid=14:kenyataanrasmi\&Itemid $=56$ (diakses 10 April 2012). Negara Berkebajikan PAS kini tanpa hukum hudud, atas laman sesawang, http:/ / www.malaysiakini.com/news/183851, (diakses 10 April 2012). Ahmad Fauzi Abdul Hamid, The New Challenges of Political Islam in Malaysia, kertas kerja dibentangkan di Persidangan Pusat Kajian Asia, Murdoch University, Perth, 12-13 Februari 2009, hal: 5 Mampukah PAS Perintah Malaysia?, Massa, 9-15 Jun 2001.

Ahmad Fauzi, The UMNO-PAS Struggle, hlm. 105.

Lihat, 17 Ramadhan Pas Lancar Konsep Negara Islam, atas laman sesawang, http:/ / subkylatif.blogspot.com/2003/10/17-ramadhan-paslancar-konsep-negara.html, (diakses 10 April 2012).

Satu Lagi Sandiwara Politik?, Massa, 29 September - 5 Oktober 2001.

Mujahid Yusof, Menuju PAS Baru: Krisis, Peluang dan Dinamisme, Kuala Lumpur: The Malaysian Insider, 2011.

Buku Jingga Agenda Pakatan Rakyat, Ubah Sekarang, Selamatkan Malaysia!, ttp, tp, tth.

Mukhriz: DAP, PKR berjaya pengaruhi PAS tukar prinsip, http:/ / www. malaysiakini.com/news/166051 (diakses 15 Februari 2012).

Ibid, hlm. 24.

Istilah kumpulan Erdogan merujuk kepada nama Perdana Menteri Turki Recep Tayyip Erdogan yang mewakili parti Islam moderat untuk disesuaikan dengan situasi politik di negara itu yang pro sekular. Kumpulan ini kebanyakan terdiri daripada berlatarbelakang profesional di dalam PAS yang menentang idea penyatuan PAS dan UMNO dalam kerjasama politik atas nama membela Melayu dan Islam. Dalam muktamar PAS ke-57 pada bulan Jun 2011, kumpulan ini berjaya menguasai beberapa jawatan strategik dalam PAS termasuk Timbalan Presiden yang secara tradisinya dipegang oleh golongan ulama semenjak kepimpinan ulama diperkenalkan pada awal tahun 1980-an. Lihat, Tsunami' Erdogan landa PAS, laman sesawang, http://www.malaysiakini.com/news/166006 (diakses 15 April 2012).

Menurut Hasan Ali, mantan Pesuruhjaya PAS Selangor yang dipecat kerana berkonflik dengan PR tentang isu murtad di Damansara, AJK PAS sekarang ini dikuasai 72 peratus berlatar belakang kumpulan Erdogan. Lihat, Hasan: 72 peratus kepimpinan PAS dikuasai golongan sekular, laman sesawang, http://malaysiakini.com/news/188288 (diakses 15 April 2012).

70 Lihat, Siapa berkuasa dalam PAS - Erdogan atau ulama?, dalam laman sesawang, http://www.freemalaysiatoday.com/2011/06/04/siapaberkuasa-dalam-pas-erdogan-atau-ulama (diakses 15 April 2012).

Ceramah Road Show Hasan Ali di Dataran Prima Saujana Kajang, 6 Mac 2012.

Pada mulanya, parti politik Islam yang diasaskan pada era reformasi sejumlah 42 parti. Akan tetapi tujuh parti tidak dapat disertakan dalam proses pemilihan oleh kementerian dalam negeri kerana tidak cukup 
syarat. Pada akhirnya, hanya 20 parti politik Islam sahaja yang diluluskan untuk bertanding dalam pilihan raya. Lihat, Arskal Salim GP, Partai Islam dan Relasi Agama-Negara, Jakarta: IAIN Syarif Hidayatullah, 1999.

Zainal Abidin Amir, Peta Islam Politik Pasca Soeharto, Jakarta: LP3ES, 2003, hlm. 239.

Lihat Susan Blackburn, Pemilu: The 1999 Indonesian Election, Clayton: Monash University, 1999.

Ali Said Damanik, Fenomena Partai Keadilan: Transformasi 20 Tahun Gerakan Tarbiyah di Indonesia, Jakarta: Teraju, 2002.

Seperti Partai Persatuan Pembangunan (PPP), PKB dan PAN. PPP merupakan parti peninggalan Orde Baru yang diasaskan pada 1971. PKB menjadi parti yang mewakili golongan Islam yang tergabung dalam NU dan PAN memiliki asas dan sokongan yang kuat daripada Muhammadiyah.

Sebelum menjadi PKS, parti ini dikenali sebagai Partai Keadilan (PK). Disebabkan perolehan suara PK pada pilihan raya 1999 tidak mencukupi batas minima perolehan suara 2,5 peratus yang ditetapkan suruhanjaya pilihan raya, PK berubah menjadi PKS bagi membolehkan PK bertanding semula pada pilihan raya berikutnya.

Pemilu 1999, http://www.kpu.go.id/index.php?option=com content\&task=view\&id=42 (Diakses pada 4 Julai 2012).

Burhanuddin Muhtadi, Dilema PKS: Suara dan Syariah, Jakarta: Kepustakaan Gramedia Popular, 2012, hlm. 178.

Selain beraktiviti politik sebagaimana parti-parti politik lain, PKS juga dikenali sebagai parti yang bijak dalam menonjolkan persepsinya sebagai parti yang ambil berat terhadap masalah rakyat dengan membuat program turun padang seperti membantu mangsa banjir, mangsa gempa, gotong royong penduduk dan aksi sosial yang lain.

Burhanuddin, Dilema PKS, hlm. 66.

Ubah Citra Islamis-Kanan, PKS Usung Jargon 'PKS untuk Semua', http:/ / us.news.detik.com/read/2010/06/16/154037/1379536/10ubah-citraislamis-kanak-pks-usung-jargon-pks-untuk-semua?nd992203605 (diakses pada 5 Februari 2012).

PKS: Jadi Partai Terbuka Adalah Ajaran Islam, http:/ / us.politik.vivanews. com/news/read/158845-dua-pengalaman-berharga-pks-ke-keterbukaan. (diakses 5 Februari 2012).

Munas II PKS Bahas Kemungkinan Non Muslim Jadi Pengurus Partai, laman sesawang, http://us.news.detik.com/read/2010/06/16/1912 58/1379722/10/munas-ii-pks-bahas-kemungkinan-non-muslim-jadipengurus-partai (diakses 5 Februari 2012).

Burhanuddin, Dilema PKS, hlm. 181.

Terima Nonmuslim, Ini Revolusi Internal PKS, http:/ / us.politik.vivanews. com/news/read/158228--terima-nonmuslim--ini-revolusi-internal-pks(diakses 5 Februari 2012).

Kelompok ini juga dikenali sebagai kumpulan 'keadilan' di dalam tubuh parti. Kumpulan ini terdiri daripada para aktivis dan tokoh-tokoh awal yang menjadi pengasas parti. Selain dikenali sebagai kumpulan golongan 
tua parti yang mewakili pandangan konservatif, kumpulan ini juga yang menghendaki idealisme parti dikekalkan sebagai parti dakwah yang konsisten kepada jalur dakwah dan tidak terlalu mengejar kuasa dalam perjuangan parti.

Dikenali juga sebagai kumpulan 'sejahtera'. Kumpulan ini sering dinisbatkan kepada aktivis muda parti yang progresif yang sekarang menguasai kepimpinan parti. Istilah 'sejahtera' yang dilekatkan kepada kumpulan ini disebabkan gaya hidup mereka yang selesa dan mewah, bertolak belakang dengan kehidupan kumpulan tua yang sederhana dan tidak mementingkan jawatan. Kumpulan ini juga dikenali sebagai kubu hizb yang pragmatik dan oportunistik. Burhanuddin, Dilema PKS, hlm. 217.

$90 \quad$ Ibid, hlm. 222.

91 Majelis Pertimbangan Pusat (MPP) PKS, Platform Kebijakan Pembangunan Partai Keadilan Sejahtera: Terwujudnya Masyarakat Madani yang Adil, Sejahtera dan Bermartabat, ttp, tp, tth, hlm. 50. Mujahid, Mепијu PAS Baru, hlm. 157-160.

Pemecatan Hasan Ali dapat dilihat sebagai bentuk pertembungan pendekatan dan cara menangani parti di antara kubu konservatif yang diterajui kumpulan ulama dan kubu profesional-pragmatikal yang didukung kumpulan Erdogan. Hasan Ali dilihat mengancam keutuhan, perpaduan dan persefahaman di antara parti komponen PR, setelah Hasan Ali banyak mengeluarkan kenyataan-kenyataan yang bertentangan dengan dasar PR yang telah dipersetujui bersama. Ini termasuk yang berkaitan dengan ketidaksetujuan Hasan Ali terhadap manifesto negara berkebajikan yang dianggapnya sebagai bentuk penyelewengan dasar parti yang seharusnya konsisten memperjuangkan negara Islam. Untuk liputan media mengenai pemecatan Hasan Ali, lihat, PAS Pecat Hasan Ali, http://malaysiakini.com/news/186013, Hasan Ali: Saya dipecat kerana Anwar Ibrahim, http:/ / malaysiakini.com/news/186049 (diakses 15 Februari 2012). Kantan Permai Kajang Selangor, Isnin 9 April 2012. Ibid. Selamat Tinggal PKS dan PKSWatch, http://pkswatch.blogspot.com/ (diakses pada 15 Februari 2012). Burhanuddin, Dilema PKS, hlm. 250.

98 Ibid., hlm. 208.

99 Perbincangan lanjut tentang perubahan pola pengundian dan pendekatan politik Islam di Indonesia, lihat William R. Liddle, New Pattern of Islamic Politics in Democratic Indonesia, dalam Piety and Pragmatism: Trends in Indonesian Islamic Politics, Washington: Woodrow Wilson International Centre, Asia Special Report No. 10, 2003.

100 Lihat Noorhaidi Hasan, "The Salafi Movement in Indonesia: Transnational Dynamics and Local Development", Comparative Studies of South Asia, Africa and the Middle East, 27 (1), 2007. 